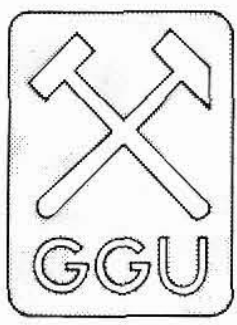

\title{
Petroleum-geological activities in 1992: preparation and support for licensing rounds offshore West Greenland
}

\author{
Flemming G. Christiansen, Christian Marcussen \\ and T. C. R. Pulvertaft
}

On 26 March 1992 the Danish Minister for Energy formally approved the opening of the first licensing round offshore West Greenland to be held since 1975. At the same time it was announced that this licensing round would be the first of three rounds to be held offshore West Greenland at 2-3 year intervals, the present round covering the area between $62^{\circ}$ and $66^{\circ} \mathrm{N}$ and the future rounds areas to the north. Naturally, compilation and circulation of information directly related to the present licensing area was a high priority activity for the Geological Survey of Greenland (GGU) in the first part of the year. The information package 'Offshore West Greenland - Exploration Information', specially prepared by GGU for the licensing round, includes the following items: reprints or preprints of four papers summarising the geology and known petroleum potential of the region, a short report on ice conditions in the licensing area, a bibliography, and catalogues of all seismic and well log data. In April a special issue of the GHEXIS Newsletter summarising licensing terms and explaining work requirements was sent out, and in May presentations were held in Copenhagen, London, Houston and Calgary. In all 29 oil companies and 19 consultancies and providers of technical services attended these presentations, at which the political-administrative framework and licensing terms were presented by the Mineral Resources Administration for Greenland, the geological setting and petroleum potential by GGU, and the logistics of exploration in Greenland by Nunaoil $\mathrm{A} / \mathrm{S}$. In June another issue of the GHEXIS Newsletter was sent out in which the substance of the presentations was summarised, largely for the benefit of companies that had been unable to attend the meetings. Three companies visited GGU for individual presentations.

In addition to these activities directed specifically towards the oil industry, papers on the geology and petroleum potential of offshore southern West Greenland were given at the 4th Conference on Petroleum Geology of NW Europe held in London 29 March - 1 April (Chalmers et al., 1993), and at the Annual Convention of the American Association of Petroleum Geologists held in Calgary in June. Papers and posters on the Jameson Land basin were also presented at these meetings (Christiansen et al., 1993), and GGU contributed to a poster on 'Sources of geological and exploration information in NW Europe' at the London conference.

In spite of all these efforts, the 1993 licensing round offshore West Greenland did not attract any applications. This lack of interest probably reflects the depressed state of the international oil industry, low oil

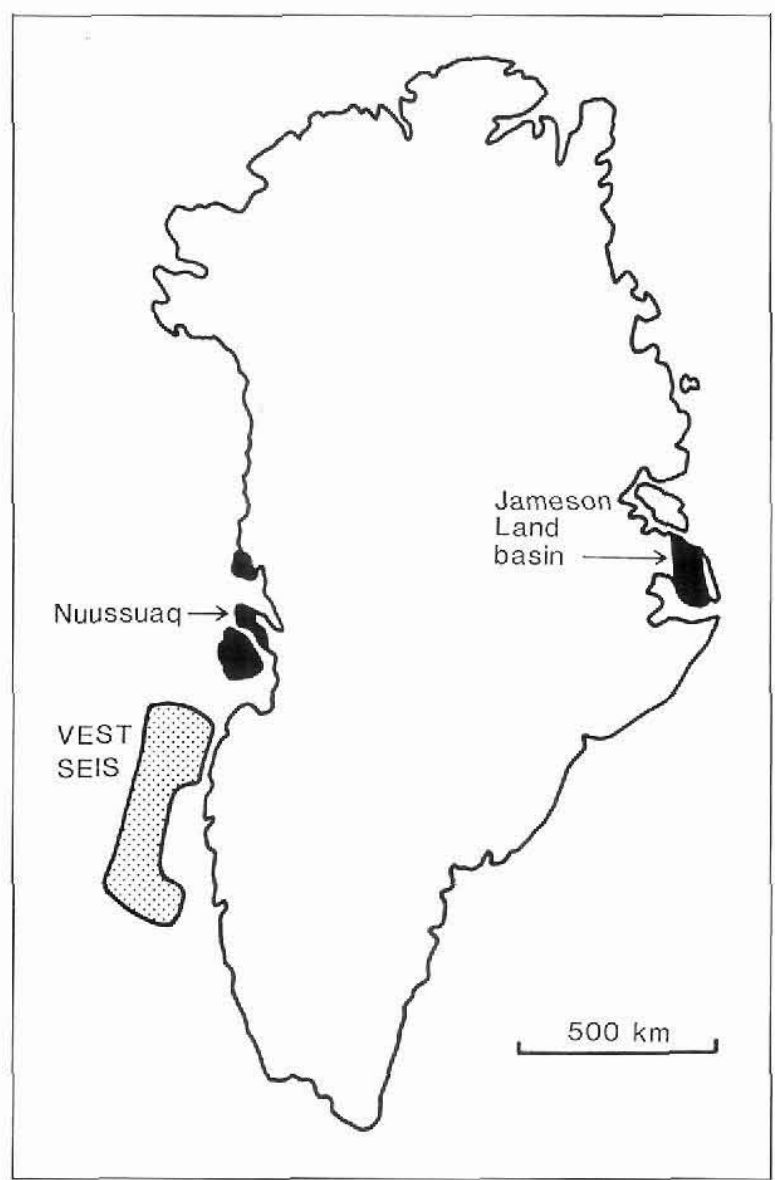

Fig. 1. Map showing areas of GGU's petroleum-gcological activity in 1992. 
prices, and competition from other areas on offer in other parts of the world. It was a blow to hopes in West Greenland that so many other countries, from Mongolia to Argentina, chose to open up new areas at the same time as the West Greenland round was announced. The scope of this competition was not foresecable, and the resulting overcommitment in the international oil industry was commented on in Oil \& Gas Journal in October 1992. In this context, arctic areas with difficult operational conditions stand at a distinct disadvantage.

Given the negative response to the licensing round, it is all the more important for petroleum geological activities at GGU to be directed primarily at collecting more information that can interest industry in West Greenland with regard to future licensing rounds. In 1992 field work on the onshore exposures of Cretaceous-Tertiary sediments and basalts of West Greenland (Fig. 1) was continued with a view to providing information on controls of potential source and reservoir rock development and on the timing of structural events in the region. Offshore West Greenland $3017 \mathrm{~km}$ of reflection scismic data were acquired, mainly in the area between $66^{\circ}$ and $68^{\circ} \mathrm{N}$ which is to be offered for licensing in the next licensing round (Fig. 2).

In the laboratory GGU has recently acquired a laser videodisc recorder in order to establish an illustrated palynomorph database. Analogue illustrations of all reference palynomorphs collected and described in the ongoing onshore West Greenland project will be registered in this database, which will be made accessible to interested research workers.

Ficld work in the Jameson Land basin of East Greenland (Fig. 1) in 1992 was limited to a short visit by a single field party. However, considerable progress was made with 1-D modelling of the basin.

More peripheral to petroleum-geological activities at GGU are the preparations for the 1993 Ocean Drilling Program Leg 152 off South-East Greenland (Larsen, this report). Apart from the prime objective for ODP Leg 152, which is the study of volcanic rifted margins, the Leg 152 holes will provide valuable control for interpreting the seismic data acquired offshore SouthEast Greenland in 1980-82 (North Atlantic D project Larsen, 1983). In connection with a site survey, approximately $2800 \mathrm{~km}$ of shallow seismic data were acquired in the area surrounding the drill sites.

\section{Onshore West Greenland}

The Upper Cretaceous - Tertiary sediments exposed on Disko, Nuussuaq (former spelling Nûgssuaq) and Svartenhuk Halvø $\left(69^{\circ}-72^{\circ} \mathrm{N}\right)$ provide important information for evaluating the exploration potential of the

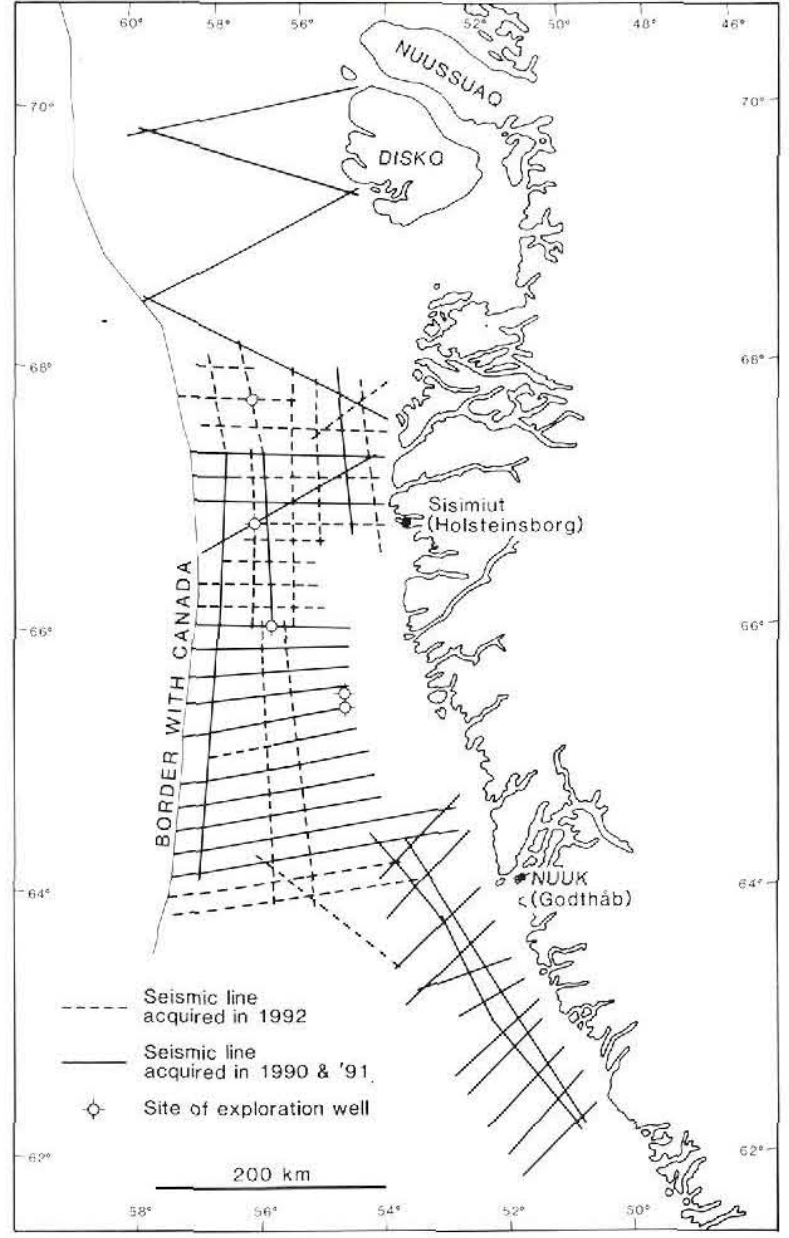

Fig. 2. Map showing position of lines acquired in the VEST SEIS seismic programme.

neighbouring offshore basins in West and North-West Greenland. Field studies were carried out in 1991-92, in the second year including a drilling programme, as part of the GGU Disko Bugt Project, with special emphasis on sedimentology of the non-marine Cretaceous succession, and sedimentology, palynostratigraphy and organic geochemistry of the marine Cretaceous and Tertiary succession (Kalsbeek \& Christiansen, 1992; Christiansen et al., 1992a; Christiansen, this report).

The main aim of this multidisciplinary work is to integrate all sedimentological, palynological and organic geochemical data within a sequence stratigraphic framework that can be applied for prediction of potential reservoir and source rocks in the offshore basins, and to establish the timing of structural events.

Of particular significance is the discovery of oil-impregnated basalts on the south coast of Nuussuaq (Fig. 3) (see Christiansen, this report). This non-degraded oil 


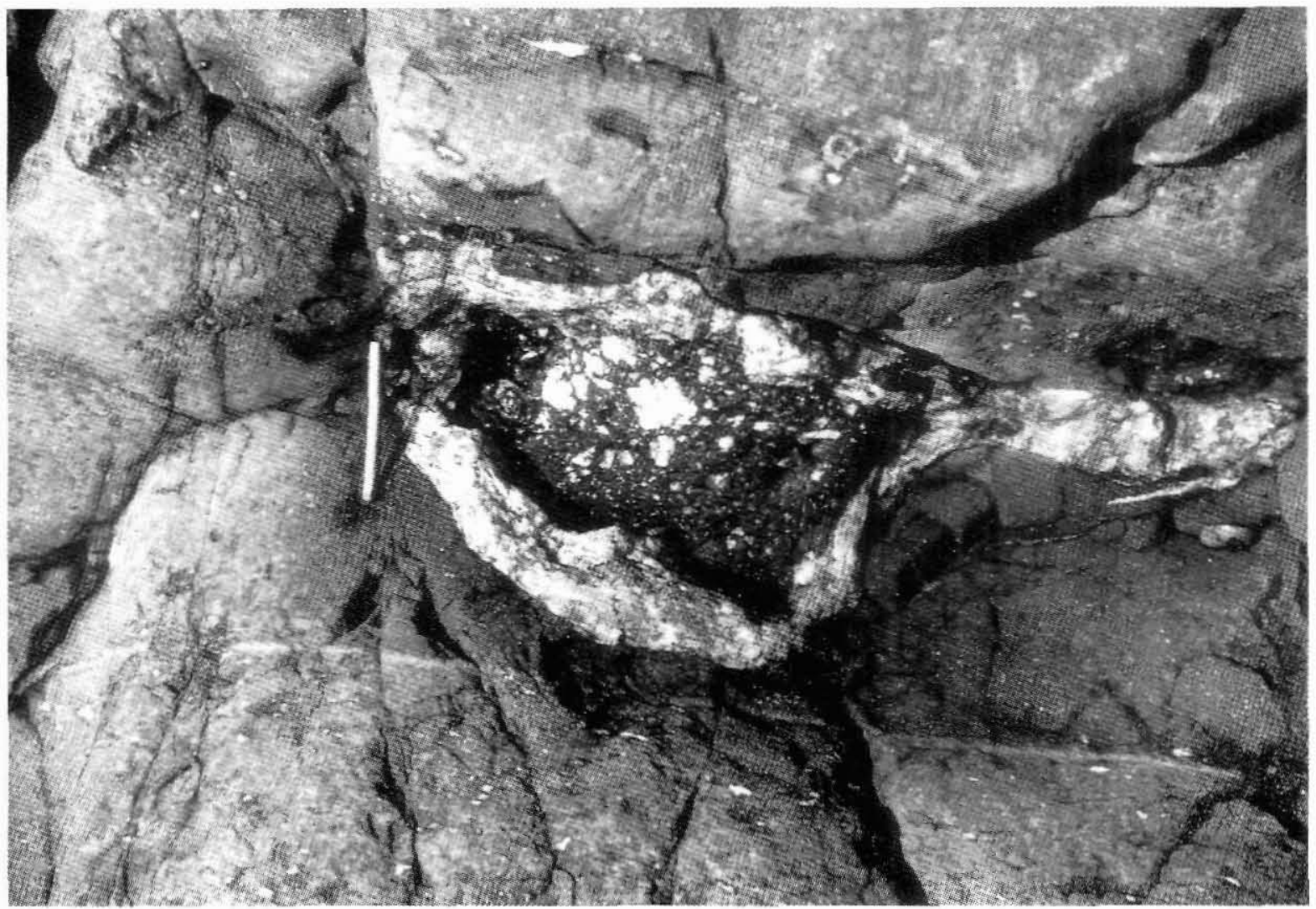

Fig. 3. Oil-stained basalts near Marraat Killiit on the south side of Nuussuaq. Photo: A. K. Pedersen

has a distinct composition that suggests origin from an oil-prone source rock of Tertiary age that furthermore is dominated by terrestrially derived organic matter. This observation opens up the possibility of completely new play types not considered by Chalmers et al. (1993) who described only play types based on a Turonian-Cenomanian marine source rock.

\section{Offshore West Greenland}

As a continuation of project SYD VEST SEIS, which acquired seismic data on the southern West Greenland shelf in 1990 and 1991 (Chalmers \& Dahl-Jensen, 1991; Christiansen \& Pulvertaft, 1992), the project VEST SEIS 92 was initiated by GGU in order to acquire new high quality seismic data offshore West Greenland between $66^{\circ}$ and $68^{\circ} \mathrm{N}$, an area expected to be opened in a future licensing round in 1995 or 1996. Furthermore, a few seismic lines south of $66^{\circ} \mathrm{N}$ were planned in order to extend the coverage of the SYD VEST SEIS project, in particular to provide more tie lines. The project was funded by the Mineral Resources Administration for Greenland. An agreement was reached with Nunaoil
A/S, operator of the KANUMAS project, to use the Danish Navy high ice-class fisheries inspection vessel Thetis, which was refitted in 1991 to accommodate seismic equipment in connection with the KANUMAS project. Acquisition for project VEST SEIS 92 took place between 30 June and 3 August 1992, a total of 33 days. The survey started in Nuuk and finished in Reykjavik, Iceland, where the KANUMAS group took over Thetis. The total length of the seismic lines recorded in this period was $2789 \mathrm{~km}$, a mean of $84.5 \mathrm{~km} /$ day. On the best day $178 \mathrm{~km}$ were acquired. After an initial downtime of 5 days mainly due to technical problems with the streamer, downtime due to weather and technical problems was limited.

Due to the coldest May in West Greenland since systematic records have been kept, part of the survey area (that just east of the Canadian border between $66^{\circ}$ and $68^{\circ} \mathrm{N}, 56^{\circ}$ and $58^{\circ} \mathrm{W}$ ) was still covered by ice ('vestisen') in July. In order to monitor the ice situation special ice maps for the area were requested from the Danish Meteorological Institute, and the ship's helicopter was used for extensive ice reconnaissance. Due to ice some of the E-W lines had to be abandoned before 


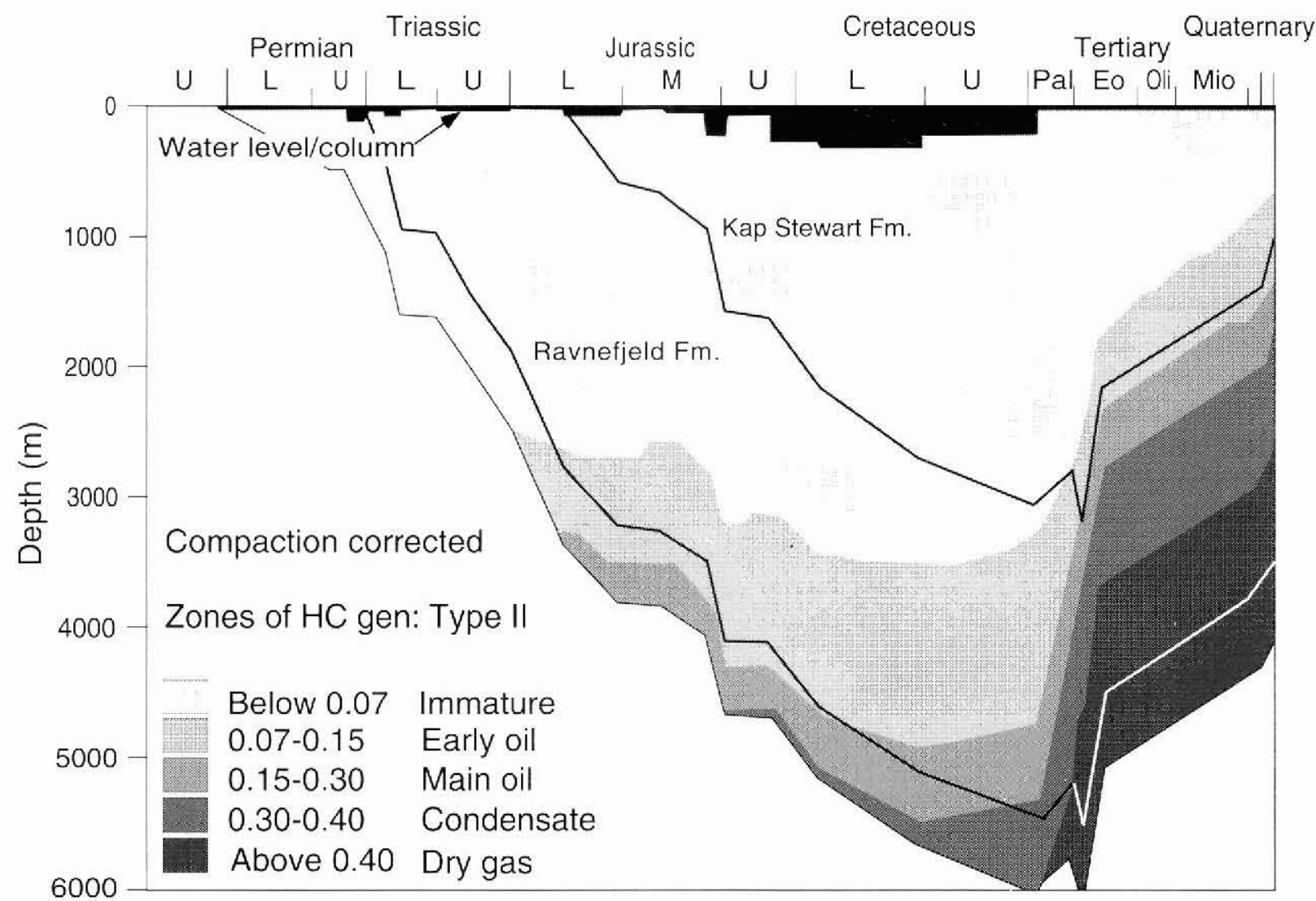

Fig. 4. Example of basin modelling results from Jameson Land showing the subsidence history and hydrocarbon generation zones of the Hugin $\mathrm{S} \phi$ pseudo-well $\left(70^{\circ} 46^{\prime} \mathrm{N}, 24^{\circ} 05^{\prime} \mathrm{W}\right)$. The two oil-prone source rocks, the Upper Permian Ravnefjeld Formation (presently in the dry gas zone) and the Lower Jurassic Kap Stewart Formation (presently close to the boundary between early and main oil generation) are shown as black lines.

reaching the border with Canada. However, after completion of a successful KANUMAS survey in Melville Bugt, with Nunaoil A/S as operator, in which $4080 \mathrm{~km}$ new data were acquired in less than a month, Thetis returned to the area, and on 19 and 20 September 228 $\mathrm{km}$ of seismic data were acquired in that part of the area covered by ice in July. This increased the total length of the seismic lines recorded in 1992 to $3017 \mathrm{~km}$ (Fig. 2). Originally the KANUMAS group had hoped to continue acquisition off North-East Greenland, but by midAugust it had become clear that ice conditions were not going to permit seismic acquisition in this area, and it was therefore decided to move to Melville Bugt.

After a competitive tender and test processing, the processing contract for the VEST SEIS 92 data was awarded to Spectrum Energy \& Information Technology Ltd. in England. At the time of writing brute stacks of all lines have been received by GGU, and tests are being carried out, in particular to find out how the strong sea-bed multiples can best be removed.

\section{Onshore East Greenland}

The Jameson Land basin in East Greenland is now considered as 'open acreage' for future exploration. Consequently GGU continues its petroleum-geological activities and promotion of the basin with the hope that exploration will be renewed in the coming years.

Field activities in the basin were limited in 1992; only one GGU team, financed by CONOCO Norway, visited the area. This was to obtain supplementary information on the Lower Jurassic succession. However, many of the studies carried out in the last decade were continued or finalised in 1992, and more intense field work including shallow drilling is likely to be started in 195. This work will take place as a collaboration between GGU and the University of Copenhagen.

The basin modelling of the Jameson Land basin was continued in 1992 using a total of 21 1-D pseudo-wells in order to describe the subsidence, uplift and thermal history of the basin. The modelling is being carried out in collaboration with the Danish Modelling Group at 
the Geological Survey of Denmark. All available seismic and field data are used as input data. A division with 22 time events from the Early Permian to Early Tertiary and up to 15 events of Tertiary uplift has been applied. The following key data are described for each event: lithology, duration, thickness, palaeobathymetry, porosity, palaeotemperature and heat flow. Thermal maturity data (especially sterane isomerisation) and apatite fission track data have been used to optimise the models (Fig. 4).

The results of the modelling have made it possible to evaluate with much greater confidence the prospectivity of the Upper Palaeozoic play types described by Christiansen $e t$ al. (1993) and of the Lower Jurassic Kap Stewart Formation play (Dam, this report). It is now clear that there are serious maturity problems with the Upper Palaeozoic plays throughout most of Jameson Land, with the exception of the Upper Permian carbonate plays in the northwestern part of the area. Most petroleum generation from the prolific oil-prone source rocks of Carboniferous and Permian age took place during the Cretaceous, and during the Early Tertiary oil was either thermally degraded or migrated into subtle stratigraphic traps in the overlying succession.

On the other hand the Lower Jurassic play seems to have an adequate maturity in a very large area in southern Jameson Land. Furthermore, both the Lower Jurassic and the Upper Jurassic succession may be prospective beneath the waters of Scoresby Sund. Up-dip migration from the sediments underlying the basalts south of Scoresby Sund may have taken place, which would significantly increase the petroleum potential of the fjord area.

Several noteworthy papers on the Jameson Land basin and the basins in North-East Greenland were published in 1992 (Christiansen et al., 1992b, c; Dam \& Surlyk, 1992; Larsen \& Marcussen, 1992; Stemmerik 1993; Stemmerik et al., 1993a, b). A summary of the BP-financed study of the Upper Triassic - Lower Jurassic succession in Jameson Land is given by Dam (this report).

\section{References}

Chalmers, J. A. \& Dahl-Jensen, T. 1991: Project SYD VEST SEIS - $3285 \mathrm{~km}$ of multichannel seismic data acquired on the southern West Greenland shelf. Rapp. Grønlands geol. Unders. 152, 21-23.

Chalmers, J. A., Pulvertaft, T. C. R., Christiansen, F. G., Larsen, H. C., Laursen, K. H. \& Ottesen, T. G. 1993: The southern West Greenland continental margin: rifting history, basin development and petroleum potential. In Parker, J. R. (ed.) Petroleum geology of Northwest Europe: Proceedings of the 4th conference. Spec. Publ. geol. Soc. London.
Christiansen, F. G. \& Pulvertaft, T. C. R. 1992: Petroleumgeological activities in 1991: reassessment of areas of earlier exploration and improvement of information service to industry. Rapp. Grønlands geol. Unders. 155, 28-30.

Christiansen, F. G., Dam, G., McIntyre, D. J., Nøhr-Hansen, H., Pedersen, G. K. \& Sønderholm, M. 1992a: Renewed petroleum geological studies onshore West Greenland Rapp. Grønlands geol. Unders. 155, 31-35.

Christiansen, F. G., Dam, G., Piasecki, S. \& Stemmerik, L. 1992b: A review of Upper Palaeozoic and Mesozoic source rocks from onshore East Greenland. In Spencer, A. M. (ed.) Generation, accumulation and production of Europe's hydrocarbons II. Spec. Publ. Europ. Ass. Petrol. Geoscien tists 2, 151-161.

Christiansen, F. G., Larsen, H. C., Marcussen, C., Hansen, K., Krabbe, H., Larsen, L. M., Piasecki, S., Stemmerik, L. \& Watt, W. S. 1992c: Uplift study of the Jameson Land basin, East Greenland. Norsk Geol. Tidsskr. 72, 291-294.

Christiansen, F. G., Larsen, H. C., Marcussen, C., Piasecki, S. \& Stemmerik, L. 1993: Late Palaeozoic plays in East Greenland. In Parker, J. R. (ed.) Petroleum geology of Northwest Europe: Proceedings of the 4th conference. Spec. Publ. geol. Soc. London.

Dam, G. \& Surlyk, F. 1992: Forced regressions in a large waveand storm-dominated anoxic lake, Rhaetian-Sinemurian Kap Stewart Formation, East Greenland. Geology 20, 749752.

Kalsbeek, F. \& Christiansen, F. G. 1992: 'Disko Bugt Project 1991, West Greenland. Rapp. Grønlands geol. Unders. 155, $36-41$.

Larsen, H. C. 1983: Marine geophysical investigations offshore East Greenland. Rapp. Grønlands geol. Unders. 115, 93100 .

Larsen, H. C. \& Marcussen, C. 1992: Sill-intrusion, flood basalt emplacement and deep crustal structure of the Scoresby Sund region, East Greenland. In Storey, B. C., Alabaster, T. \& Pankhurst, R. J. (ed.) Magmatism and the causes of continental break-up. Spec. Publ. geol. Soc. London 68, 365-386.

Stemmerik, L. 1993: Moscovian bryozoan-dominated buildups, northern Amdrup Land, eastern North Greenland. In Vorren, T. O. et al. (ed.) Arctic geology and petroleum potential. Spec. Publ. Norwegian Petrol. Soc. 2, 99-106.

Stemmerik, L., Christiansen, F. G., Piasecki, S., Jordt, B., Marcussen, C. \& Nøhr-Hansen, H. 1993a: Depositional history and petroleum geology of the Carboniferous to Cretaceous sediments in the northern part of East Greenland. In Vorren, T. O. et al. (ed.) Arctic geology and petroleum potential. Spec. Publ. Norwegian Petrol. Soc. 2, 67-88.

Stemmerik, L., Scholle, P. A., Henk, F. H., Di Liegro, G. \& Ulmer, D. S. 1993b: Sedimentology and diagenesis of the Upper Permian Wegener Halvø Formation carbonates along the margins of the Jameson Land Basin, East Greenland. In Vorren, T. O. et al. (ed.) Arctic geology and petroleum potential. Spec. Publ. Norwegian Petrol. Soc. 2, 107-119.

F. G. C., C. M. \& T. C. R. P., Geological Survey of Greenland, Copenhagen. 